\section{Effectiveness of a conservation energy model for febrile neutropenia in children with cancer}

\author{
Khoirunnisa Khoirunnisa, ${ }^{1,2}$ \\ Allenidekania Allenidekania, ${ }^{1}$ \\ Happy Hayati ${ }^{1}$ \\ 1Faculty of Nursing, Universitas \\ Indonesia; ${ }^{2}$ Akademi Keperawatan \\ RSPAD Gatot Soebroto Jakarta
}

\begin{abstract}
Febrile neutropenia is a complication of chemotherapy that occurs in children with cancer. This paper aimed to provide an overview of the application of the Levine Energy Conservation Model for treating fever neutropenia in children with cancer. The method involved a case study of five children with cancer treated for febrile neutropenia using the nursing process approach. The nursing process, according to the Levine Energy Conservation Model, focuses on increasing the body's adaptability through four forms of conservation, namely, the conservation of energy, personal integrity, structural integrity, and social integrity. Trophicognosis in the five cases under management identified hyperthermia and the risk of infection transmission. Other nursing problems were nutritional imbalances that were less than the body's needs and the risk of bleeding. These problems can hinder the process of adapting children with cancer to the challenges of disease and the treatment of side effects in achieving self-integrity.
\end{abstract}

\section{Introduction}

There are around 11,000 cases of children with cancer in Indonesia every year, and there are around 650 cases of cancer in children in Jakarta. ${ }^{1}$ Following the Riskesdas report of 2016, the occurrence of leukemia in Indonesia was determined at 2.8 cases per 100,000 , with eye cancer at 2.4 cases per 100,000 and bone cancer at 0.9 cases per 100,000 . In cases of child cancer, chemotherapy is the main treatment option. However, chemotherapy can also cause some side effects, both physical and psychological, in both children and adults. ${ }^{2}$ The content of cytotoxic chemotherapy drugs can suppress the process of hematopoiesis that occurs in the bone marrow. ${ }^{3}$ This causes immunosuppression, which results in a decrease in the number of blood components, including the neutrophils in white blood cells. The decrease in the number of neutrophils is called neutropenia. ${ }^{4}$

Neutropenia is a complication frequently found in children suffering from cancer who are actively undergoing chemotherapy. 5 Neutropenia is a condition in which neutrophil counts in white blood cells are less than normal $\left(1000 \mathrm{~mm}^{3}\right){ }^{6}$ Febrile neutropenia is a state of neutropenia accompanied by symptoms of an increase in body temperature. Febrile neutropenia is the most common complication in hospitals in immunosuppressed children, with fever as a sign of infection.?

The care provided to overcome neutropenia must be implemented immediately because neutropenia can increase the risk of infection, which can worsen a child's condition. The treatment of neutropenia involves the multidisciplinary participation of health workers. Nurses have a role in the management of neutropenia, namely, in terms of preventing infection. ${ }^{8,9}$ Levine's energy conservation nursing model focuses on maintaining the body's energy. The model covers four forms of bodily conservation, namely, the conservation of energy, personal integrity, social integrity, and structural integrity. Infection of the body can increase the metabolism in an individual's body. This arises due to an increase in body temperature, which causes an increase in the rate of metabolism so that the energy needed becomes greater. 10

Energy conservation, as developed by Mary J. Levine, aims to maintain the integrity of bodily functions and improve individual adaptation to disturbances that might occur, which could have an impact on achieving an optimal energy balance for each individual. ${ }^{11}$ The final result of the energy balance process in children is their adaptation to such disturbances, which can improve their quality of life.

\section{Materials and Methods}

This research used a case study with a nursing process approach. The nursing process was carried out by applying the Levine Energy Conservation Model and was conducted using critical thinking, including an assessment, trophicognosis, composition of hypotheses, interventions, and nursing evaluations. The subjects of this study were five children with cancer who experienced febrile neutropenia, with absolute neutrophil counts (ANCs) $<1000 / \mathrm{mm}^{3}$.
Correspondence: Allenidekania Allenidekania, Pediatric Nursing Department, Faculty of Nursing, Universitas Indonesia; Jalan Prof. Dr. Bahder Djohan, Kampus UI Depok, West Java, 16424 Indonesia.

Tel.: +6221.78849120 - Fax: +6221.7864124.

E-mail: alleni@ui.ac.id

Key words: Children with cancer; Levine Energy Conservation Model; febrile neutropenia.

Acknowledgments: We would like to express our gratitude to all children with cancer and their parents who were willing to participate in this study.

Funding: This work was supported by Hibah PITTA B 2019, funded by DRPM Universitas Indonesia (No. NKB-0483/UN2.R3.1/HKP.05. 00/2019)

Contributions: KK, AA, and HH conceived the idea and plan of the research. KK and HH contributed to the design and implementation of the research also verified the analytical method. KK wrote the manuscript in consultation with AA and $\mathrm{HH}$. All authors discussed the result and reviewed the final manuscript.

Ethical approval: The implementation of this evidence-based practice received ethical approval from the Research Ethics Committee of the Faculty of Nursing Universitas Indonesia (No. 20/UN2.F12.D/HKP.02.04/2019)

Conflict of interest: There is no conflict of interest in this study.

This work is licensed under a Creative Commons Attribution NonCommercial 4.0 License (CC BY-NC 4.0).

(C) Copyright: the Author(s), 2020

Licensee PAGEPress, Italy

Pediatric Reports 2020; 12(s1):8697

doi:10.4081/pr.2020.8697

\section{Results}

\section{Case 1}

A boy named D, 15 years old, with a diagnosis of LMA, $5^{\text {th }}$ day of care. At the time of assessment, the main complaint was that of fever for two days. The parents said the peak of body temperature was $38.4^{\circ} \mathrm{C}$. Presence of bruises in the right knee and both hands of the child. Hemoglobin $(\mathrm{Hb})$ value: $6.9 \mathrm{gr} / \mathrm{dL}$, platelets: $5000 / \mathrm{mm}^{3}$, hematocrit (Ht): 19.2\%, leukocytes: $2740 / \mathrm{mm}^{3}$, ANC: $81 / \mathrm{mm}^{3}$, BP: $107 / 85 \mathrm{mmHg}$, HR: 115 $\mathrm{x} /$ minute, RR: $20 \mathrm{x} /$ minute, body temperature: $38.0^{\circ} \mathrm{C}, \mathrm{SpO} 298 \%$, BW: $55,6 \mathrm{~kg}, \mathrm{BH}$ : $165 \mathrm{~cm}$. There were complaints of nausea. The child had good nutritional status and his 
hydration status was adequate, with a positive fluid balance and no signs of overload. The child's rest and sleep statuses were adequate.

\section{Case 2}

A girl named G, 7 years old, with LMA, $2^{\text {nd }}$ day of treatment. At the time of assessment, the child had had a fever for two days with a peak of $40^{\circ} \mathrm{C}$. The child also complained of nausea and of having vomited twice, one day before admission to hospital. There were petechiae in the child's right hand. Conjunctiva anemic, $\mathrm{Hb}$ value: 6.8 gr/dL, Ht: $18.4 \%$, leukocytes: $330 / \mathrm{mm}^{3}$, platelets: $5000 / \mathrm{mm}^{3}$, ANC $39 / \mathrm{mm}^{3}$, BP: 89/65 mmHg, HR: $140 \mathrm{x} /$ minute, RR: 30 $\mathrm{x} /$ minute, body temperature $40.30^{\circ} \mathrm{C}, \mathrm{SpO}_{2}$ : 98\%, BW: $23 \mathrm{~kg}, \mathrm{BH}: 120 \mathrm{~cm}$. The child's nutritional status was good, with mild chest retraction. The child's hydration status was adequate, with a positive fluid balance and without any signs of overload. The child's rest and sleep statuses were adequate.

\section{Case 3}

A girl named D, 6 years old, with rhabdomyosarcoma, $2^{\text {nd }}$ day of treatment. According to the mother, complaints of fever one day with a peak of $38.9^{\circ} \mathrm{C}$. The left eye of the child was removed; at present, the child sees with one eye. The child experienced alopecia. $\mathrm{Hb}: 10.3 \mathrm{gr} / \mathrm{dL}, \mathrm{Ht}$ : $27.3 \%$, leukocytes $1500 / \mathrm{mm}^{3}$, platelets:

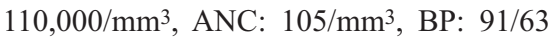
mmHg, HR: $152 \mathrm{x} /$ minute, RR: $22 \mathrm{x} / \mathrm{min}-$ utes, body temperature: $38.60^{\circ} \mathrm{C}, \mathrm{SpO}_{2}$ : 99\%, BW: $20 \mathrm{~kg}, \mathrm{BH}: 120 \mathrm{~cm}$. The nutritional status of the child was poor. The child complained of nausea and vomiting. She wanted to eat only three tablespoons. The child's hydration status was adequate, with a positive fluid balance and without any signs of overload. The child's rest and sleep statuses were adequate.

\section{Case 4}

A girl named S, 15 years old, with osteosarcoma, $3^{\text {rd }}$ day of care. At the time of assessment, according to her mother, the child had complained of fever for three days. The peak fever was $38^{\circ} \mathrm{C}$. Fever complaints were accompanied by nausea and vomiting twice. The mother also said that the child was having difficulty accepting the condition of her body, walking with crutches. The child did not talk much or tell stories. The child seemed introverted and did not want to communicate other than with her family; that is, her mother. The child lacked in support from peers and siblings because she was far from home. The results of the study also found that there were sur- gical wounds on the child's right knee that had healed. The wounds were dry and not covered in gauze. The child had alopecia. $\mathrm{Hb}: 10 \mathrm{gr} / \mathrm{dL}$, Ht: 30\%, leukocytes $3000 / \mathrm{mm}^{3}$, platelets: $264,000 / \mathrm{mm}^{3}$, ANC: $306 / \mathrm{mm}^{3}$, Humpty Dumpty score was 9 (low risk), BP: 126/91 mmHg, HR: 95 $\mathrm{x} /$ minute, RR: $18 \mathrm{x} /$ minute, body temperature $37.60^{\circ} \mathrm{C}, \mathrm{SpO}_{2}: 98 \%, \mathrm{BW}: 41 \mathrm{~kg}, \mathrm{BH}$ : $146 \mathrm{~cm}$, LLA: $22.5 \mathrm{~cm}$, malnutrition. The child's hydration status was adequate, with a positive fluid balance and without any signs of overload. The child's rest and sleep statuses were adequate.

\section{Case 5}

A girl named T, 5 years old, with acute lymphoblastic leukemia, 5th day of care. According to the mother, the child had complained of fever for five days. The peak fever was $39^{\circ} \mathrm{C}, \mathrm{Hb}: 10.8 \mathrm{gr} / \mathrm{dL}$, Ht: $30.4 \%$, leukocytes: $8080 / \mathrm{mm}^{3}$, platelets: $25,000 / \mathrm{mm}^{3}$, ANC: $424 / \mathrm{mm}^{3}$, warmed acral, petechiae on both legs, BP: 90/60 mmHg, HR: 100 $\mathrm{x} /$ minute, RR: $25 \mathrm{x} /$ minute, body temperature: $38.6^{\circ} \mathrm{C}, \mathrm{SpO}_{2}$ : $99 \%$, BW: $16 \mathrm{~kg}, \mathrm{BH}: 94$ $\mathrm{cm}$, LLA: $16 \mathrm{~cm}$. The child had good nutritional status and ate half portions. The child's hydration status was adequate, with a positive fluid balance and without any signs of overload. The child's rest and sleep statuses were adequate.

\section{Discussion}

This case study discussed five cases of malignancy in children, namely acute lymphoblastic leukemia, acute myeloblastic leukemia, osteosarcoma, and rhabdomyosarcoma. In these five cases of malignancy, the same nursing problems were found, namely hyperthermia. The increase in body temperature experienced by the children in the five cases managed reached more than $38^{\circ} \mathrm{C}$. This was consistent with the results of research conducted by Rasmy et al., which stated that children with cancer would experience a fever. ${ }^{9}$ Widya et al. also stated that there were around $58 \%$ of cancer patients in children who had a fever. ${ }^{3}$ Neutrophils are granulocyte cells that are effective in maintaining the body, especially against bacterial infections. The mechanism of fever in the case of neutropenia is uncertain, but it may occur due to the release of endogenic pyrogens from the bone marrow where blood cells are produced. 12

The treatment of hyperthermia carried out in the five cases collaborated with the administration of paracetamol and regular water compresses. This was in line with the research conducted by Budiana and Febiani that the handling of children who experienced an increase in body temperature of more than $38^{\circ} \mathrm{C}$ was given paracetamol and antibiotics as empirical therapy. ${ }^{13}$ This is in line with the concept of the energy conservation model developed by Levine. The child's body required to do energy conservation to speed up the healing process in the child's body. ${ }^{14}$

Two of the five cases examined, the patients had poor nutritional status. Children's nutritional status is related to the metabolic processes of the child's body to obtain energy. ${ }^{15}$ Children with poor nutritional status will interfere with the metabolic processes that occur in the child's body so that the energy produced is not optimal. Whereas, in accordance with Levine's energy conservation model, the child's body needs to carry out energy maintenance to accelerate the healing process and keep the child from the risk of infection that increases due to the state of neutropenia they experience. Child energy conservation also can be seen from the child's hemoglobin value. Hemoglobin is a protein that carries oxygen and nutrients containing iron, so the value of hemoglobin is related to the status of oxygenation and child nutrition. 15 Of the five cases observed, the children experienced a significant decrease in hemoglobin value, i.e., less than $10 \mathrm{gr} / \mathrm{dL}$. This certainly has an impact on the child's oxygenation status. One child showed mild chest retraction as an effort to compensate the body to increase oxygen intake into the body. ${ }^{15}$

In five cases above, all the patients experienced a decrease in the number of leukocytes and ANC. Decreasing the number of ANCs that were less than normal could increase the children's risk of infection. In children suffering from cancer who are undergoing chemotherapy, the incidence of neutropenia is very likely to occur because of the reaction of chemotherapy drugs that are cytotoxic, causing children to experience immunosuppressants. 5 Immunosuppressants put children at risk for infection. This can increase the energy needs of the child's body as an effort in healing from infection. It is suitable for Levine's energy conservation model that the child's body needs to do energy conservation to accelerate the healing process in the child's body. ${ }^{14}$

The handling of the risk of infection can be done with infection prevention management. Management of prevention of infections carried out involves the multidisciplinary role of health workers, including doctors, nurses, other health workers who work in hospitals, and families. Management of prevention of infection includes personal hygiene, oral hygiene, environmental 
hygiene, adequate nutrient intake, and administration of antibiotics and antifungal drugs. 9,16 Management of prevention of this infection begins with education about signs of infection symptoms, personal hygiene procedures, and environmental controls that is necessary to be done by parents, patients, and health workers in the hospital. Management of infection prevention is also included in efforts to help the child's body conserve energy with the ultimate goal of healing the child's body.

The nursing evaluation carried out by looking at four conservation issues. The results of nursing evaluations indicated an improvement in energy conservation, namely the problem of pediatric hyperthermia. On the fifth day of treatment, the children had not experienced hyperthermia with body temperature in the normal range, namely $36.5-37.5^{\circ} \mathrm{C}$. Disruption in the conservation of the patient's structural integrity has improved in the laboratory value of blood, namely an increase in hemoglobin value and leukocyte value. According to Nurdiana (2015), the hemoglobin value can increase due to adequate iron-containing food patterns. ${ }^{17}$ In addition, the increase in leukocyte value also affects the improvement of ANC values experienced by children so that it can be said that the risk of infection in children is improved as well. ${ }^{17}$ The state of neutropenia in patients suffering from cancer is influenced by the suppression of blood production in the bone marrow that occurs as a result of cytotoxic drugs. ${ }^{4}$ The ANC value can be influenced by folic acid levels in the body. ${ }^{18}$ So as to increase the ANC value, it is necessary to improve the production of blood in the bone marrow and increase the folic acid level. 4 The evaluation required by observing the organismic response of the patients towards intervention conducted.

\section{Conclusions}

Cancer children who are undergoing chemotherapy are very likely to experience neutropenia as a complication of chemotherapy. One of the effects of chemotherapy is the suppression of blood cell production in the bone marrow, which results in a decrease in ANC value. This decrease in ANC can increase a child's risk of infection. The application of Levine's energy conservation model in children with febrile neutropenia can help the child's body manage its energy. So that the body's energy can be used to help the body's healing process from infection. The evaluation results in each case showed varied results and indicated adaptability in maintaining conservation principles, one of which was a decrease in body temperature, as a sign of infection. Nurses are expected to be able to provide infection prevention interventions in children with cancer.

\section{References}

1. Centre of Data and Information. Stop kanker: Situasi penyakit kanker. The Ministry of Health Republic of Indonesia; 2015. Available from: https://pusdatin.kemkes.go.id/article/vi ew/15090700004/situasi-penyakitkanker.html

2. Arini T, Widjajanto PH, Haryanti F. The relationship between fatigue and play activities of children with acute lymphoblastic leukemia receiving chemotherapy. Int J Med Sci 2015;3:53-60.

3. Widya RA, Nugroho S, Winarsih S, Yulistiani Y. Analysis of ANC levels after filgrastim therapy in acute leukimia children with neutropenia. Folia Medica Indonesiana 2019;55:10-6.

4. Yarbro CK, Wujcik D, Gobel BH. Cancer nursing principles and practice. 7th ed. Sudbury, Massachusetts: Jones \& Barlett Publisher; 2011.

5. Barton CD, Waugh LK, Nielsen MJ, Paulus S. Febrile neutropenia in children treated for malignancy. J Infection 2015;71:S27-S35.

6. Windiastuti E, Nency YM, Mulatsih S, et al. Buku ajar hematologi-onkologi anak. Revised ed. Jakarta: Badan Penerbit Ikatan Dokter Anak Indonesia; 2018.

7. Loeffen EAH, te Poele EM, Tissing WJE, et al. Very early discharge versus early discharge versus non-early discharge in children with cancer and febrile neutropenia. Cochrane Database Syst Rev 2016:1-32.

8. Wang XJ, Chan A. Optimizing symptoms and management of febrile neutropenia among cancer patients: Current status and future directions. Curr Oncol Rep 2017;19.

9. Rasmy A, Amal A, Fotih S, Selwi W. Febrile neutropenia in cancer patient: Epidemiology, microbiology, pathophysiology and management. J Cancer Prev Curr Res 2016;5:1-8.

10. Hockenberry M, Wilson D. Wong's essentials of pediatric nursing. 9th ed. St. Louis, MO: Mosby; 2013.

11. Parker ME, Smith MC. Nursing theories \& nursing practice. 3rd ed. Philadelphia: FA Davis Company; 2010.

12. Ismoedijanto I. Demam pada anak. Sari Pediatri 2000;2:103-8.

13. Budiana ING, Febiani M. Febrile neutropenia pada pasien pascakemoterapi. Indonesian Journal of Cancer 2017;11: 77-82.

14. Alligood M. Nursing theorists and their work. 8th ed. St. Louis, MO: Mosby; 2014. pp 746.

15. Pearce EC. Anatomi dan fisiologi untuk paramedis. Jakarta: PT. Gramedia Pustaka Utama; 2009.

16. Ariza-Heredia EJ, Chemaly RF. Update on infection control practices in cancer hospitals. CA Cancer J Clin 2018;68: 340-55.

17. Nurdiana N. Factors affecting the level of hemoglobin on junior high school children on coast regional district of North Lombok. Jurnal Biota: Biologi dan Pendidikan Biologi. 2015;8:1-18.

18. Ward E, DeSantis C, Robbins A, et al. Childhood and adolescent cancer statistics. CA Cancer J Clin 2014;64:83-103. 